УдК 616.35 - $089: 615.849$

DOI 10.11603/2414-4533.2019.4.10707

\author{
(В. В. БАЛИЦЬКИЙ ${ }^{1,2}$, М. П. ЗАХАРАШ ${ }^{3}$, О. Г. КУРИК ${ }^{4}$
}

Вінницький національний медичний університет імені М. І. Пирогова ${ }^{1}$ Хмельницька обласна лікарня²

Національний медичний університет імені О. О. Богомольця⿱ Київ

Державна наукова установа "Науково-практичний центр профрілактичної та клінічної медицини" Державного управління справами", Київ

\title{
Застосування сучасних хірургічних технологій у лікуванні поеднаної патології анального каналу і прямої кишки
}

\begin{abstract}
Мета роботи: порівняльна оцінка ефективності використання апаратів високочастотної електрохірургії “ЕRBE ICC 200”, “ЭФА”, “KLS Martin”, а також апарата радіохвильової хірургії “Surgitron” для лікування пацієнтів із поєднаною патологією анального каналу і прямої кишки.

Матеріали і методи. Проаналізовані результати лікування 586 пацієнтів із поєднаною патологією анального каналу і прямої кишки. 3 використанням апарата радіохвильової хірургії “Surgitron” було прооперовано 245 (41,8 \%) хворих, апарата високочастотної електрохірургії “ЕRВЕ ICC 200” - 169 (28,8 \%) хворих, апарата високочастотної електрохірургії “ЭФА” - 114 (19,4 \%) хворих, апарата високочастотної електрохірургї “KLS Martin” - 58 (9,9 \%) хворих.

Результати досліджень та їх обговорення. При застосуванні апарата радіохвильової хірургії “Surgitron” тривалість

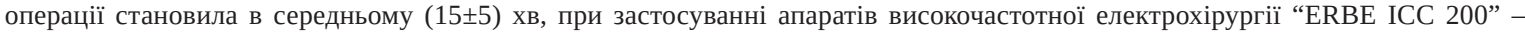

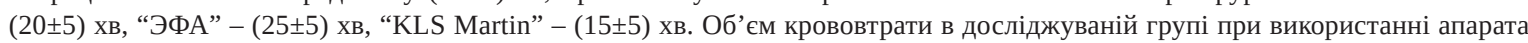

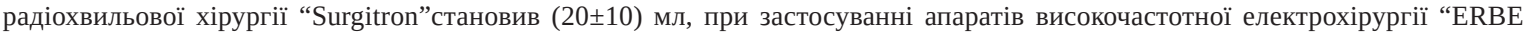

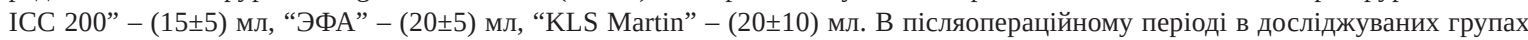
при використанні апарата радіохвильової хірургії “Surgitron”, а також високочастотних електрохірургічних апаратів “ЕRВЕ

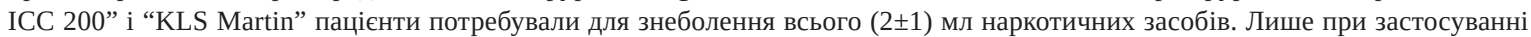

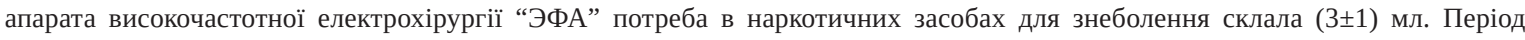

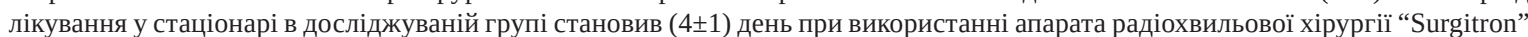
та високочастотного електрохірургічного апарата “KLS Martin”, при застосуванні апарата високочастотної електрохірургії

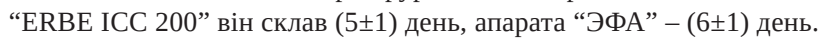

Ключові слова: поєднана патологія; анальний канал; пряма кишка; високочастотна електрохірургія; радіохвильова хірургія.

Постановка проблеми і аналіз останніх досліджень та публікацій. Впродовж останніх двох-трьох десятиліть спостерігається загальносвітова тенденція до стрімкого зростання кількості проктологічних захворювань, серед яких питома вага поєднаної патології анального каналу і прямої кишки прогресивно збільшується, іноді сягаючи 65 \% [1].

Поєднаній патології анального каналу і прямої кишки присвячена досить незначна кількість публікацій з результатами наукових досліджень, що зумовлено відсутністю єдиного підходу до вирішення даної проблеми.

Частина авторів позитивно ставиться до поєднаних оперативних втручань завдяки скороченню ліжко-днів та відсутності необхідності у повторній операції. Інші вважають, що після поєднаних операцій вищим є відсоток ускладнень і виконувати такі операції потрібно тільки за суворими показаннями [2].

Впродовж останнього десятиліття широкого застосування набули “гібридні” операції в лікуванні хронічного геморою III-IV стадії в комбінації з іншою патологією анального каналу і прямої кишки. Вони включають поєднання деартерилізації гемороїдальних вузлів із мукопексією або латексне лігування гемороїдальних вузлів, їх ліфтинг та мукопексію з видаленням супутньої патології анального каналу [3, 4]. Ці оперативні втручання значно покращують безпосередні та віддалені анатомічні та функціональні результати хірургічного лікування як геморою, так і супутньої аноректальної патології, але вони також, на жаль, не позбавлені недоліків. Серед ускладнень таких операцій виділяють тромбоз зовнішнього гемороїдального вузла (2 - 5,7 \%), гостра анальна тріщина (2 \%), післяопераційна кровотеча (12 \%), випадання гемороїдальних вузлів (6,6 \%), формування гіпертрофованих періанальних шкірних міток $(75 \%)[5,6]$.

Швидкий розвиток сучасних хірургічних технологій сприяв активному впровадженню в колопроктологічну практику нових високотехнологічних методів хірургічного лікування різноманітної патології анального каналу і прямої кишки. Так, однією з перших широкого використання в колопроктології набула електротермічна система "Liga Sure” для хірургічного лікування ге- 
морою. Вона забезпечувала ретельний гемостаз, втричі скорочувала тривалість операції, зменшувала кількість дизуричних явищ, а також вдвічі зменшувала терміни реабілітації пацієнтів. Але, на жаль, дана методика мала ряд недоліків: післяопераційні кровотечі (1,6-2,5 \%), стриктури анального каналу $(2,1-2,8 \%)$, рецидиви захворювань (7,5 \%) [7].

Широкого використання в колопроктології набув ультразвуковий гармонічний скальпель “Ultra Cision” компанії Ethicon Endo-Surgery (США), принцип дії якого побудований на коливанні робочої насадки, що призводить до руйнування водневих сполук в білкових структурах колагену та їх склеювання. Внаслідок цього відбувається обтурація просвіту кровоносних судин до 3-х мм у діаметрі. Глибина термічного впливу не перевищує 1,5 мм. Вказані властивості дають можливість проводити оперативні втручання без прошивання судин із мінімальним термічним впливом на тканини анального каналу, що дозволяє зменшити тривалість операції та інтенсивність післяопераційного больового синдрому [8]. Однак цей метод супроводжується виникненням післяопераційних кровотеч (2-6,1 \%), вираженим больовим синдромом (5 \%), тривалим загоєнням післяопераційних ран (6 \%) та рецидивами захворювань $(9,1 \%)[9,10]$.

Останнім часом все більше авторів рекомендують використовувати для хірургічного лікування аноректальної патології радіохвильовий скальпель "Surgitron" виробництва компанії Ellman International (США). Принцип дії даного апарата полягає в атравматичному розрізі та коагуляції м'яких тканин за допомогою високочастотних радіохвиль, викликаючи в тканинах утворення тепла, під впливом якого відбувається розпад клітинних структур та їх випаровування і виникає ефект “розходження” тканин. При цьому теплове пошкодження тканин є мінімальним, а максимальна глибина коагуляційного некрозу складає 0,1-0,2 мм, що створює сприятливі умови для загоєння ран, а також сприяє зменшенню терміну їх загоєння, скороченню ліжко-днів та термінів непрацездатності хворих $[11,12]$. Перевагами високочастотної $(3,8$ - 4 МГц) радіохвильової хірургії є: мінімальне пошкодження тканин, прискорення процесів їх регенерації, стерилізуючий ефект радіохвиль із вказаною частотою, гарний косметичний ефект [13]. Але існує думка, що гемостатичні властивості радіохвильового апарата $є$ недостатніми, особливо у присутності біологічних рідин, що вимагає додаткового лігування судин та знижує його ефективність під час гемороїдектомії [14].
Таким чином, актуальність проблеми поєднаної патології анального каналу і прямої кишки $є$ досить високою і сприяє створенню та запровадженню в практику колопроктологів сучасних малоінвазивних і високоефективних методів хірургічного лікування даної патології, які б мали мінімальний пошкоджуючий вплив на тканини, забезпечували відсутність ускладнень та рецидивів в післяопераційному періоді, зменшували терміни стаціонарного лікування пацієнтів і сприяли б їх швидкій медико-соціальній реабілітації.

Мета роботи: порівняльна оцінка ефективності використання апаратів високочастотної електрохірургії “ЕRBE ICC 200”, “ЭФА”, “KLS Martin”, а також апарата радіохвильової хірургії "Surgitron” для лікування пацієнтів з поєднаною патологією анального каналу і прямої кишки.

Матеріали і методи. У період із січня 2007 року по лютий 2019 року у відділенні проктології Хмельницької обласної лікарні прооперовано 586 пацієнтів із поєднаною патологією анального каналу і прямої кишки з використанням високочастотних електрохірургічних апаратів "ERBE ICC 200”, “ЭФА”, “KLS Martin”, а також апарата радіохвильової хірургії “Surgitron”. 3 них 340 (58 \%) пацієнтів були чоловічої статі та 246 пацієнтів (42 \%) - жіночої статі. Вік пацієнтів коливався від 18 до 76 років.

Так, за період з вересня 2009 року по лютий 2019 року було прооперовано 245 пацієнтів із поєднаною патологією анального каналу і прямої кишки 3 використанням апарата радіохвильової хірургії “Surgitron”, які склали першу дослідну групу. 3 них 143 (58,4 \%) пацієнти були чоловічої статі та 102 (41,6 \%) - жіночої статі. Вік пацієнтів коливався від 18 до 74 років.

3 березня 2008 року по лютий 2019 року було прооперовано 169 пацієнтів із поєднаною патологією анального каналу і прямої кишки з використанням апарата високочастотної електрохірургії “ERBE ICC 200”, які склали другу дослідну групу. 3 них 104 (61,5 \%) пацієнти були чоловічої статі та 65 (38,5 \%) - жіночої статі. Вік пацієнтів коливався від 20 до 76 років.

У період з січня 2007 року по лютий 2019 року було прооперовано 114 пацієнтів із поєднаною патологією анального каналу і прямої кишки з використанням апарата високочастотної електрохірургії “ЭФА”, які склали третю дослідну групу. 3 них 65 (57 \%) пацієнтів були чоловічої статі та 49 (43 \%) - жіночої статі. Вік пацієнтів коливався від 24 до 72 років.

3 жовтня 2017 року по лютий 2019 року було прооперовано 58 пацієнтів з поєднаною патоло- 
гією анального каналу і прямої кишки з використанням апарата високочастотної електрохірургії “KLS Martin”, які склали четверту дослідну групу. 3 них 24 (41,4 \%) пацієнти були чоловічої статі та 34 пацієнти (58,6 \%) - жіночої статі. Вік пацієнтів коливався від 19 до 65 років.

Контрольну групу склали 112 пацієнтів з поєднаною патологією анального каналу і прямої кишки, які були прооперовані традиційно з використанням металевого скальпеля.

Всім пацієнтам перед операцією було проведено огляд періанальної і параректальних ділянок, виконано пальцеве дослідження анального каналу і прямої кишки, ректороманоскопію, а також з метою дообстеження і виключення патології ободової кишки, 235 (40,1 \%) пацієнтам старше 45 років було виконано іригоскопію або фіброколоноскопію.

Усі 586 пацієнтів, які були розподілені на 4 дослідні групи, підписували добровільну інформовану згоду на проведення знеболення та виконання оперативних втручань, які були здійснені під спинномозковою анестезією.

Результати досліджень та їх обговорення. У результаті дослідження було встановлено, що у першій дослідній групі у 188 пацієнтів (76,7 \%) було виявлено 2 патології, у 51 (20,8 \%) - 3 патології, у 6 (2,5 \%) - 4 патології анального каналу і прямої кишки.

Найчастіше у цій групі зустрічались такі варіанти поєднаної патології анального каналу і прямої кишки: хронічна анальна тріщина і анальний поліп - у 45 (18,4 \%) пацієнтів, хронічна анальна тріщина і комбінований геморой - у 31 (12,6 \%) пацієнта, комбінований геморой і анальний поліп - у 23 (9,4%) пацієнтів, комбінований геморой і хронічний парапроктит - у 23 (9,4 \%) пацієнтів, зовнішній геморой і анальний поліп - у 18 (7,3%) пацієнтів, хронічна анальна тріщина, анальний поліп і гіпертрофовані періанальні шкірні мітки у 13 (5,3 \%) пацієнтів, зовнішній геморой і хронічна анальна тріщина - у 12 (4,9 \%) пацієнтів, комбінований геморой, хронічна анальна тріщина i анальний поліп - у 10 (4,1%) пацієнтів, зовнішній геморой, хронічна анальна тріщина і анальний поліп - у 10 (4,1%) пацієнтів, анальний поліп і гіпертрофовані періанальні шкірні мітки - у 10 (4,1%) пацієнтів.

Пацієнтам першої дослідної групи були виконані такі види комбінованих операцій: висічення анальної тріщини і поліпектомія - у 45 (18,4 \%) пацієнтів, висічення анальної тріщини і гемороїдектомія - у 31 (12,6 \%) пацієнта, гемороїдектомія і висічення анальної фістули - у 23 (9,4 \%) пацієнтів, гемороїдектомія і поліпектомія - у 23 (9,4%) пацієнтів, гемороїдектомія і поліпектомія - у 18 (7,3 \%) пацієнтів, висічення анальної тріщини, поліпектомія та електроексцизія гіпертрофованої періанальної шкірної мітки - у 13 (5,3 \%) пацієнтів, гемороїдектомія і висічення анальної тріщини - у 12 (4,9 \%) пацієнтів, гемороїдектомія, висічення анальної тріщини і поліпектомія - у 10 (4,1%) пацієнтів, гемороїдектомія, висічення анальної тріщини і поліпектомія - у 10 (4,1%) пацієнтів, поліпектомія та електроексцизія гіпертрофованої періанальної шкірної мітки - у 10 (4,1%) пацієнтів.

У ході проведеного дослідження було встановлено, що у другій дослідній групі в 132 пацієнтів (78,1 \%) було виявлено 2 захворювання, у 35 (20,7 \%) - 3 захворювання, у 2 (1,2 \%) - 4 захворювання анального каналу та прямої кишки.

Найчастіше у цій групі зустрічались такі варіанти поєднаної патології анального каналу і прямої кишки: хронічна анальна тріщина і анальний поліп - у 18 (10,6 \%) пацієнтів, хронічна анальна тріщина і комбінований геморой - у 14 (8,3%) пацієнтів, комбінований геморой і анальний поліп - у 14 (8,3 \%) пацієнтів, комбінований геморой і хронічний парапроктит - у 13 (7,7 \%) пацієнтів, хронічна анальна тріщина, анальний поліп і гіпертрофовані періанальні шкірні мітки - у 5 (2,9%) пацієнтів, комбінований геморой, хронічна анальна тріщина і анальний поліп - у 5 (2,9 \%) пацієнтів, зовнішній геморой і анальний поліп - у 4 (2,4 \%) пацієнтів.

Характер проведених оперативних втручань залежав від варіанту поєднаної патології анального каналу та прямої кишки. Найчастіше виконувались такі комбінації оперативних втручань: висічення анальної тріщини + поліпектомія - 18 (10,6 \%), гемороїдектомія + висічення анальної тріщини - 14 (8,3 \%), гемороїдектомія + поліпектомія 14 (8,3 \%), гемороїдектомія + висічення анальної фістули - 13 (7,7 \%), висічення анальної тріщини + поліпектомія + електроексцизія гіпертрофованої періанальної шкірної мітки - 5 (2,9%), гемороїдектомія + висічення анальної тріщини + поліпектомія - 5 (2,9 \%), гемороїдектомія + поліпектомія $-4(2,4 \%)$.

Під час дослідження у третій дослідній групі у 85 пацієнтів (74,5 \%) було виявлено 2 захворювання, у 26 (22,8 \%) - 3 захворювання, у 3 (2,7 \%) - 4 захворювання анального каналу та прямої кишки.

Найчастіше у цій групі зустрічались такі варіанти поєднаної патології анального каналу і прямої кишки: хронічна анальна тріщина і анальний поліп - у 27 (23 \%) пацієнтів, хронічна анальна 
тріщина і комбінований геморой - у 22 (19 \%) пацієнтів, комбінований геморой і хронічний парапроктит - у 18 (16 \%) пацієнтів, комбінований геморой і анальний поліп - у 15 (13 \%) пацієнтів, хронічна анальна тріщина, анальний поліп і гіпертрофовані періанальні шкірні мітки - у 8 (7 \%) пацієнтів, комбінований геморой, хронічна анальна тріщина і анальний поліп - у 8 (7 \%) пацієнтів, зовнішній геморой і хронічний парапроктит - у 6 (5\%) пацієнтів, хронічний парапроктит і анальний поліп - у 6 (5 \%) пацієнтів, хронічний внутрішній геморой III ст. і хронічна анальна тріщина - у 4 (3\%) пацієнтів.

Пацієнтам третьої дослідної групи були виконані такі комбінації оперативних втручань: висічення анальної тріщини і поліпектомія - у 27 (23 \%) пацієнтів, висічення анальної тріщини і гемороїдектомія - у 22 (19 \%), гемороїдектомія і висічення анальної фістули - у 18 (16 \%), гемороїдектомія і поліпектомія - у 15 (13 \%), висічення анальної тріщини, поліпектомія, електроексцизія гіпертрофованої періанальної шкірної мітки - у 8 (7 \%), гемороїдектомія, висічення анальної тріщини, поліпектомія - у 8 (7 \%), гемороїдектомія і висічення анальної фістули - у 6 (5 \%), висічення анальної фістули і поліпектомія - у 6 (5 \%), гемороїдектомія і висічення анальної тріщини - у 4 (3\%).

Під час проведеного дослідження у четвертій дослідній групі встановлено, що у 34 пацієнтів (58,6 \%) було виявлено 2 захворювання, у 19 (32,7 \%) - 3 захворювання, у 4 (6,9 \%) - 4 захворювання, в одній (1,8 \%) - 5 захворювань анального каналу та прямої кишки.

Найчастіше у цій групі зустрічались такі варіанти поєднаної патології анального каналу і прямої кишки: хронічна анальна тріщина і анальний поліп - у 8 (13,8 \%) пацієнтів, хронічна анальна тріщина, анальний поліп і комбінований геморой - у 8 (13,8 \%) пацієнтів, хронічна анальна тріщина, анальний поліп і гіпертрофовані періанальні шкірні мітки - у 6 (10,3 \%) пацієнтів, комбінований геморой і хронічна анальна тріщина- у 6 (10,3 \%) пацієнтів, комбінований геморой і хронічний парапроктит - у 5 (8,6 \%) пацієнтів, зовнішній геморой і хронічна анальна тріщина - у 5 (8,6 \%) пацієнтів, хронічний парапроктит і анальний поліп - у 2 $(3,4$ \%) пацієнтів, зовнішній геморой і гіпертрофовані періанальні шкірні мітки - у 2 (3,4 \%) пацієнтів, анальний поліп і гіпертрофовані періанальні шкірні мітки - у 2 (3,4 \%) пацієнтів.

Пацієнтам четвертої дослідної групи були виконані такі види комбінованих операцій при найбільш поширених варіантах поєднаної патології: висічення анальної тріщини і поліпектомія - у 8 (13,8 \%) пацієнтів, висічення анальної тріщини, поліпектомія і гемороїдектомія - у 8 (13,8 \%) пацієнтів, висічення анальної тріщини, поліпектомія та електроексцизія гіпертрофованої періанальної шкірної мітки - у 6 (10,3 \%) пацієнтів, гемороїдектомія і висічення анальної фістули - у 5 (8,6 \%) пацієнтів, гемороїдектомія і висічення анальної тріщини - у 5 (8,6 \%) пацієнтів, висічення анальної фістули і поліпектомія - у 2 (3,4 \%) пацієнтів, гемороїдектомія і електроексцизія гіпертрофованої періанальної шкірної мітки - у 2 (3,4%) пацієнтів, поліпектомія та електроексцизія гіпертрофованої періанальної шкірної мітки - у 2 (3,4%) пацієнтів.

У результаті проведеного дослідження було встановлено, що при використанні апарата радіохвильової хірургії “Surgitron” тривалість операції становила в середньому $(15 \pm 5)$ хв, при застосуванні апаратів високочастотної електрохірургії

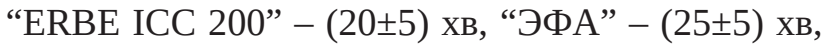
"KLS Martin" - $(15 \pm 5)$ хв, а в контрольній групі

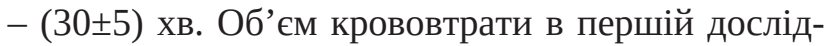
ній групі становив $(20 \pm 10)$ мл при використанні апарату радіохвильової хірургії "Surgitron", при застосуванні апарата високочастотної елек-

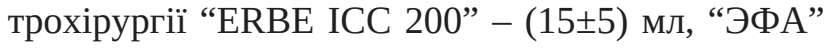

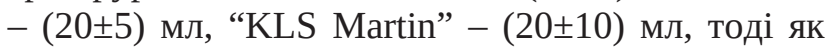
у контрольній групі - $(40 \pm 10)$ мл. Больовий синдром у післяопераційному періоді був більш виражений у пацієнтів контрольної групи, де потреба у наркотичних засобах для знеболення була $(4 \pm 1)$ мл, а у першій, другій та четвертій дослідних групах пацієнти потребували для знеболення всього $(2 \pm 1)$ мл наркотичних засобів при використанні апаратів радіохвильової хірургії “Surgitron” та високочастотних електрохірургічних апаратів “ERBE ICC 200” і “KLS Martin” відповідно. Лише при застосуванні апарата високочастотної електрохірургії “ЭФА” потреба у наркотичних за-

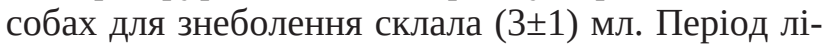
кування у стаціонарі в першій та четвертій досліджуваних групах становив $4 \pm 1$ день при використанні апаратів радіохвильової хірургії “Surgitron” та високочастотного електрохірургічного апарата “KLS Martin” відповідно, а при застосуванні апарата високочастотної електрохірургії "ЕRBE ICC

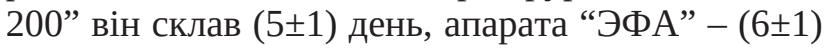
день, тоді як у контрольній групі він був більшим і становив $(7 \pm 1)$ день.

У післяопераційному періоді у пацієнтів досліджуваної групи не виявлено ознак недостатності анального сфінктера, а також формування рубцевої стриктури анального каналу, тоді як у контрольній групі у 2 (4 \%) пацієнтів було виявле- 
но формування рубцевої стриктури анального каналу, що потребувало консервативних (в одного пацієнта) та оперативних (в одного пацієнта) заходів із їх ліквідації.

Висновки. 1. Використання апарата радіохвильової хірургії “Surgitron”, а також високочастотних електрохірургічних апаратів “ЕRBE ICC 200”, “ЭФА” та "KLS Martin” для лікування пацієнтів із поєднаною патологією анального каналу і прямої кишки завдяки незначному впливу на тканини сприяє скороченню тривалості операції, зменшенню об’єму інтраопераційної крововтрати, суттєвому зниженню больового синдрому в післяопераційному періоді, скороченню термінів стаціонарного лікування пацієнтів, що зумовлює їх швидку медико-соціальну реабілітацію.

\section{СПИСОК ЛІТЕРАТУРИ}

1. Foxx-Orenstein A. E. Common anorectal disorders / A. E. FoxxOrenstein, S. B. Umar, M. D. Crowell // Gastroenterology and Hepatology. - 2014. - No. 10 (5). - P. 294-301.

2. Сравнительный анализ хирургического лечения сочетанной неопухолевой патологии анального канала и прямой кишки / А. В. Борота, А. П. Кухто, Н. К. Базиян-Кухто [ и др.] // Новообразование (Neoplasm). - 2018. - № 10 (1). - С. 18-21. 3. Рафибеков Э. Д. HAL-RAR при лечении геморроя 3-4 стадии в сочетании с сопутствующей анальной патологией / Э. Д. Рафибеков, А. А. Субанов, А. А. Айсаев // Материалы II съезда колопроктологов стран СНГ, III съезда колопроктологов Украины с участием стран Центральной и Восточной Европы. - Одесса, 2011. - С. 504-505.

4. Белоцкая Л. В. Гибридные операции при хроническом геморрое / Л. В. Белоцкая, С. Ю. Чистохин // Материалы Всероссийского съезда колопроктологов с международным участием // Колопроктология. - 2016. - № 2 (56) (приложение). - С. 14.

5. Господарський А. Я. Хірургічне лікування геморою 3-4 стадії у поєднанні з хронічною анальною тріщиною / А. Я. Господарський, Р. В. Буратинський, Р. С. Древніцький // Матеріали IV з'їзду колопроктологів України, Київ, 26-28 жовт., 2016 р. // Клінічна хірургія. - 2016. - № 10. 3 (893). - С. 86.

6. Досвід використання THD в комбінації з висіченням анальної тріщини / В. Ю. Пироговський, Б. В. Сорокін, Я. П. Фелештинський [та ін.] // Матеріали IV з'їзду колопроктологів України, Київ, 26-28 жовт., 2016 // Клінічна хірургія. - 2016. -№ 10.3 (893). - С. 90.

7. Кузьминов А. М. Геморроидэктомия с применением высоких энергий / А. М. Кузьминов, И. Ф. Борисов // Колопроктология. - 2009. - № 3 (29). - С. 46-51.
2. Застосування таких сучасних радіохірургічних та електрохірургічних технологій $є$ суттєво кращим порівняно з використанням хірургічного металевого скальпеля, оскільки завдяки мінімальному впливу на тканини забезпечують швидше загоєння післяопераційної рани, сприяють формуванню ніжного еластичного рубця та запобігають утворенню рубцевих стриктур анального каналу, а також недостатності анального сфінктера в післяопераційному періоді.

Перспективи подальших досліджень. Вивчення характеру загоєння післяопераційних ран пацієнтів із поєднаною патологією анального каналу і прямої кишки в різні терміни післяопераційного періоду від використаного шовного матеріалу та виду застосованої хірургічної технології.

8. Данилов М. А. Преимущества использования HARMONIC FOCUS при выполнении открытой геморроидэктомии / А. М. Данилов, А. О. Атрощенко, И. Е. Хатьков // Материалы Всероссийского съезда колопроктологов с международным участием // Колопроктология. - 2016. - № 2 (56) (приложение). - С. 24.

9. Оценка результатов геморроидэктомии ультразвуковым скальпелем / И. А. Мухин, А. М. Кузьминов, О. Ю. Фоменко [и др.] // Материалы Всероссийской научно-практической конференции с международным участием // Колопроктология. - 2017. - № 3 (61). - С. 35-36.

10. Модифицированная геморроидэктомия ультразвуковым скальпелем в амбулаторных условиях / Л. В. Тян, О. Г. Цой, А. С. Каукеев [и др.] // Материалы Всероссийской научнопрактической конференции с международным участием // Колопроктология. - 2017. - № 3 (61). - С. 40.

11. Соловьёв О. Л. Современная физиотерапия в лечении геморроя, анальных трещин и параректальных свищей / О. Л. Соловьёв, А. О. Соловьёв // Колопроктология. - 2011. № 2 (36). - С. 47-50.

12. Бродовський С. П. Малоінвазивні технології в хірургії анальних тріщин / С. П. Бродовський, В. В. Тарабанчук, Я. В. Бадовська // Матеріали IV з'їзду колопроктологів України // Клінічна хірургія. - 2016. - № 10.3 (893). - С. 83-84.

13. Surgical treatment with radiofrequencies for outpatients with surgical benign ano-perianal diseases / V. Radu, S. Radu, D. S. Vasilescu [et al.] // Chirurgia. - 2015. - N 3 (110). P. 244-253.

14. Vivaldi C. Radiofrequency ablation of haemorrhoids: first results of a new technique / C. Vivaldi, H. Shaefer // Colorectal Disease. - 2016. - Vol. 18, Issue1. - P. 124. 


\section{REFERENCES}

1. Foxx-Orenstein, A.E., Umar, S.B., \& Crowell, M.D. (2014). Common anorectal disorders. Gastroenterology and Hepatology, 10 (5), 294-301.

2. Borota, A.V., Kuhto, A.P., Bazijan-Kuhto, N.K., \& Borota, A.A. (2018). Sravnitelnyy analiz hirurgicheskogo lecheniya sochetannoy neopuholevoy patologii analnogo kanala $i$ pryamoy kishki [Comparative analysis of surgical treatment of combined non-tumor anal canal and rectal pathology]. Novoobrazovanie - Neoplasm, 10 (1), 18-21 [in Russian].

3. Rafibekov, E.D., Subanov, A.A., \& Aisaev, A.A. (2011). HAL-RAR pri lechenii gemorroya 3-4 stadii $v$ sochetanii $s$ soputstvuyushchey analnoy patologiey [ HAL-RAR in the treatment of hemorrhoids 3-4 stages in combination with concomitant anal pathology]. Proceedinds of the 2nd Congress of Coloproctologists of the CIS Countries, the III Congress of Coloproctologists of Ukraine with the Participation of the Countries of Central and Eastern Europe. Odessa, May 18-20 (pp. 504-505). Kyiv: Publish centre Image of Ukraine [in Russian].

4. Belotskaya, L.V., \& Chistokhin, S.Yu. (2016). Gibridnye operatsii pri khronicheskom gemorroe [Hybrid surgery for chronic haemorrhoids]. Proceedings of the All-Russian Congress of Coloproctologists with International Participation. Astrakhan, August 25-27. 2016. (pp. 14-15). Koloproktologiya Coloproctology, 2 (56) [in Russian].

5. Hospodarskyi, A.Ia., Buratynskyi, R.V., \& Drevnitskyi, R.S. (2016). Khirurhichne likuvannia hemoroiu 3-4 stadii u poiednanni $\mathrm{z}$ khronichnoiu analnoiu trishchynoiu [Surgical treatment of 3-4 stages of hemorrhoids combined with chronic anal fissure]. Proceedings of IV congress of coloproctologists of Ukraine. Kyiv, October 26-28. 2016. Klinichna khirurhiia - Clinical Surgery, 10.3 (893) [in Ukrainian].

6. Pyrohovskyi, V.Iu., Sorokin, B.V., Feleshtynskyi, Ia.P., Zadorozhnyi, S.P., Taranenko, A.O., Zlobenets, S.O., ... Noies, A.Y. (2016). Dosvid vykorystannia THD v kombinatsii z vysichenniam analnoi trishchyny [Experience of using THD in combination with excision of the anal fissure]. Proceedings of IV congress of coloproctologists of Ukraine. Kyiv, October 26-28. 2016. (p.90) Klinichna khirurhiia - Clinical Surgery, 10.3 (893) [in Ukrainian].

7. Kuzminov, A.M, \& Borisov, I.F. (2009). Gemorroidektomiya $s$ primeneniem vysokikh energiy [Haemorrhoidectomy with application of high energies]. Koloproctologiya-Coloproctology, 3 (29), 46-51 [in Russian].
8. Danilov, M.A., Atroshhenko, A.O., \& Hatkov, I.E. (2016). Preimushchestva ispolzovaniya HARMONIC FOCUS pri vypolnenii otkrytoy gemorroidektomii [Advantages of using HARMONIC FOCUS during performing open haemorrhoidectomy]. Proceedings of the All-Russian Congress of Coloproctologists with International Participation. Astrakhan, August 25-27. 2016. (p. 24). Koloproktologiya - Coloproctology, 2 (56) [in Russian].

9. Muhin, I.A., Kuzminov, A.M., Fomenko, O.Yu., Korolik, V. Yu., Minbaev, Sh.T., \& Vyshegorodtsev, D.V. (2017). Otsenka rezultatov gemorroidektomii ultrazvukovym skalpelem [Evaluation of haemorrhoidectomy results using ultrasonic scalpel]. Proceedings of the All-Russian Scientific and Practical Conference with International Participation. Voronezh, October 26-28. 2017. (p. 35-36). Koloproktologiya - Coloproctology, 3 (61) [in Russian].

10. Tyan, L.V., Tsoy, O.G., Kaukeev, A.S., Ramazanova, L.R., \& Suleymenov, A.S. (2017). Modifitsirovannaya gemorroidektomiya ultrazvukovym skalpelem v ambulatornyh usloviyakh [Modified haemorrhoidectomy by ultrasonic scalpel on an outpatient conditions]. Proceedings of the All-Russian Scientific and Practical Conference with International Participation. Voronezh, October 26-28 (p.40). Koloproktologiya - Coloproctology, 3 (61) [in Russian].

11. Solovyov, O.L., \& Solovyov, A.O. (2011). Sovremennaya fizioterapiya $v$ lechenii gemorroya, analnykh treshchin i pararektalnykh svishhey [Modern physiotherapy for treatment of haemorrhoids, anal fissures and perianal fistulas]. Koloproktologiya - Coloproctology, 2 (36), 47-50 [in Russian].

12. Brodovskyi, S.P., Tarabanchuk, V.V., \& Badovska, Ia.V. (2016). Maloinvazyvni tekhnolohii v khirurhii analnykh trishchyn [Minimal invasive technologies in anal fissure surgery]. Materials of IV Congress of Coloproctologists of Ukraine . Kyiv, October 26-28. (pp. 83-84). Klinichna khirurhiia - Clinical Surgery, 10.3 [in Ukrainian].

13. Radu, V., Radu, S., Vasilescu, D.S., Mustatea, P., \& Constantinoiu, S. (2015). Surgical treatment with radiofrequencies for outpatients with surgical benign ano-perianal diseases. Chirurgia, 3 (110), 244-253.

14. Vivaldi, C., \& Shaefer, H. (2016). Radiofrequency ablation of haemorrhoids: first results of a new technique. Colorectal Disease, 18 (1), 124. 


\author{
V. V. BALYTSKYY ${ }^{1,2}$, M. P. ZAKHARASH ${ }^{3}$, O. G. KURYK ${ }^{4}$
}

M. Pyrohov Vinnytsia National Medical University ${ }^{1}$,

Khmelnytskyi Regional Hospital ${ }^{2}$

O. Bohomolets National Medical University ${ }^{3}$, Kyiv

State Scientific Institution "Scientific-Practical Centre of Preventive and Clinical Medicine", State Administration of Affairs ${ }^{4}$, Kyiv

\title{
APPLICATION OF MODERN SURGICAL TECHNOLOGIES FOR TREATMENT OF COMBINED ANAL CANAL AND RECTAL PATHOLOGY
}

\begin{abstract}
The aim of the work: comparative assessment of effectiveness of using high-frequency electrosurgery devices "ERBE ICC 200", "EFA", "KLS Martin" and radio-wave surgery device "Surgitron" for treatment of patients with combined anal canal and rectal pathology. Materials and Methods. The treatment results of 586 patients with combined pathology of anal canal and rectum have been analyzed. Using radio-wave surgery device "Surgitron" 245 (41.8 \%) patients were operated, 169 (28.8\%) patients - high-frequency electrosurgery device "ERBE ICC 200”, 114 (19.4\%) patients - high-frequency electrosurgery device "EFA”, 58 patients (9.9 \%) - highfrequency electrosurgery device "KLS Martin".

Results and Discussion. During using radio-wave surgery device "Surgitron" the operation duration was on average (15 \pm 5 ) min, using

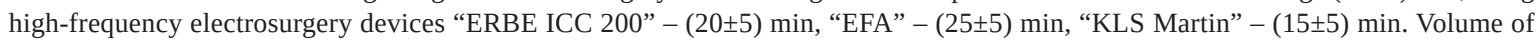
bleeding in research group with using radio-wave surgery device "Surgitron" averaged $(20 \pm 10) \mathrm{ml}$, in cases of using high-frequency

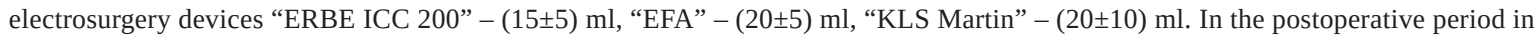
research groups with using radio-wave surgery device "Surgitron” and using high-frequency electrosurgery devices "ERBE ICC 200" and "KLS Martin" patients needed for pain relief only $(2 \pm 1) \mathrm{ml}$ narcotic drugs. Only in case of using high-frequency electrosurgery device "EFA" need of narcotic drugs for pain relief was $(3 \pm 1) \mathrm{ml}$. Inpatient period in research group with using radio-wave surgery device "Surgitron" and high-frequency electrosurgery device "KLS Martin” was (4 \pm 1$)$ days, in case of using high-frequency electrosurgery

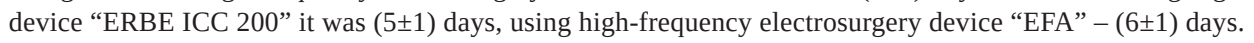

Key words: combined pathology; anal canal; rectum; high-frequency electrosurgery; radio- wave surgery .

\section{В. В. БАЛИЦКИЙ ${ }^{1,2}$, М. П. ЗАХАРАШ ${ }^{3}$, Е. Г. КУРЫК ${ }^{4}$}

Винницкий национальный медицинский университет имени Н. И. Пирогова ${ }^{1}$ Хмельницкая областная больница

Национальный медицинский университет имени А. А. Богомольца ${ }^{3}$, Киев

Государственное научное учреждение "Научно-практический центр профилактической и клинической медицины"

Государственного управления делами ${ }^{4}$, Киев

\section{ПРИМЕНЕНИЕ СОВРЕМЕННЫХ ХИРУРГИЧЕСКИХ ТЕХНОЛОГИЙ В ЛЕЧЕНИИ СОЧЕТАННОЙ ПАТОЛОГИИ АНАЛЬНОГО КАНА.А И ПРЯМОЙ КИШКИ}

Цель работы: сравнительная оценка эффективности использования аппаратов высокочастотной электрохирургии “ERBE ICC 200”, “ЭФА”, “KLS Martin”, а также аппарата радиоволновой хирургии “Surgitron” для лечения пациентов с сочетанной патологией анального канала и прямой кишки.

Материалы и методы. Проанализированы результаты лечения 586 пациентов с сочетанной патологией анального канала и прямой кишки. С использованием аппарата радиоволновой хирургии “Surgitron” было прооперировано 245 (41,8 \%) больных, аппарата высокочастотной электрохирургии “ERBE ICC 200” - 169 (28,8 \%) больных, аппарата высокочастотной электрохирургии “ЭФА” - 114 (19,4 \%) больных, аппарата высокочастотной электрохирургии “KLS Martin” - 58 (9,9 \%) больных.

Результаты исследований и их обсуждение. При применении аппарата радиоволновой хирургии "Surgitron” длительность операции составляла в среднем (15 55) мин, при применении аппаратов высокочастотной электрохирургии “ERBE ICC 200” -

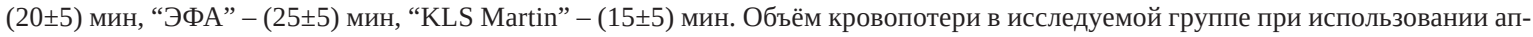
парата радиоволновой хирургии “Surgitron”составлял $(20 \pm 10)$ мл, при применении аппаратов высокочастотной электрохирур-

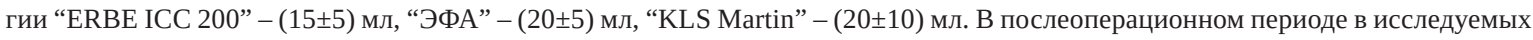
группах при использовании аппарата радиоволновой хирургии “Surgitron”, а также высокочастотных электрохирургических

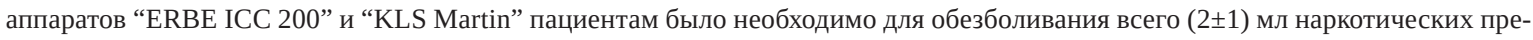
паратов. Только при применении аппарата высокочастотной электрохирургии “ЭФА” потребность в наркотических препаратах для обезболивания составила ( $3 \pm 1)$ мл. Период лечения в стационаре в исследуемой группе составил $(4 \pm 1)$ день при использовании аппарата радиоволновой хирургии “Surgitron” и высокочастотного электрохирургического аппарата “KLS Martin”, при

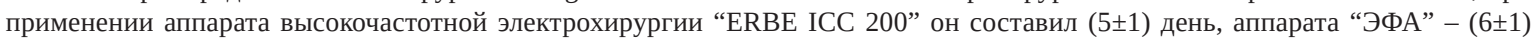
день.

Ключевые слова: сочетанная патология; анальный канал; прямая кишка; высокочастотная электрохирургия; радиоволновая хирургия. 